Mеталлофиз. новейшие технол. / Metallofiz. Noveishie Tekhnol. (C) 2015 ИМФ (Институт металлофизики 2015 , т. 37, № 3, сс. 347-354

Оттиски доступны непосредственно от издателя

им. Г. В. Курдюмова НАН Украины)

Фотокопирование разрешено только

Напечатано в Украине.

в соответствии с лицензией

PACS numbers: 61.05.cp, 68.37.Hk, 68.55.J-, 68.55.Nq, 81.15.Pq, 82.45.Qr

\title{
Joint Effect of Chromium and Nickel on Surface Morphology and Preferred Crystal Orientations of Electrodeposited Iron-Based Coatings
}

\author{
Ie. V. Kolesnyk \\ SHEI 'Ukrainian State University of Chemical Technology', \\ 8 Gagarin Avenue, \\ 49005 Dnipropetrovs'k, Ukraine
}

Structural investigations of electrodeposited binary and ternary iron-based alloys containing chromium and nickel are accomplished by the methods of scanning electron microscopy and X-ray diffractometry. Joint effect of the alloying elements on the surface morphology and preferred crystal orientations in $\mathrm{Fe}-\mathrm{Cr}-\mathrm{Ni}$ alloys' coatings electrodeposited from sulphate electrolyte on steel substrate is shown and explained. The surface morphology of the investigated $\mathrm{Fe}-\mathrm{Cr}-\mathrm{Ni}$ alloys with b.c.c. crystal structure is represented solely by spherulites and is accompanied by prevalence of $<111>$ crystal orientation in contrast to electrodeposited iron where regular fine crystal structure is characterized by preferred $<211>$ crystal orientation.

Методами растрової електронної мікроскопії та рентґенівської дифрактометрії виконано структурні дослідження електроосаджених подвійних та потрійних стопів на основі заліза, що містять хром і нікель. Показано та пояснено сумісний вплив легувальних елементів на морфологію поверхні та переважні орієнтації кристалів у покриттях на основі стопів $\mathrm{Fe}-\mathrm{Cr}-\mathrm{Ni}$, електроосаджених із сульфатного електроліту на сталеве підложжя. Морфологія поверхні досліджених стопів $\mathrm{Fe}-\mathrm{Cr}-\mathrm{Ni}$ з ОЦК-структурою представлена виключно сферолітами, що супроводжується переважанням $<111>$-орієнтації кристалів, на відміну від електроосадженого заліза, в якому звичайна дрібнокристалічна структура характеризується переважною $<211>$-орієнтацією кристалів.

Методами растровой электронной микроскопии и рентгеновской дифрактометрии выполнены структурные исследования электроосаждённых двойных и тройных сплавов на основе железа, содержащих хром и никель. Показано и объяснено совместное влияние легирующих элементов на морфологию поверхности и преимущественные ориентации кристаллов в покрытиях на основе сплавов $\mathrm{Fe}-\mathrm{Cr}-\mathrm{Ni}$, электроосаждённых из сульфатного электролита на стальную подложку. Морфология поверхно- 
сти исследованных сплавов $\mathrm{Fe}-\mathrm{Cr}-\mathrm{Ni}$ с ОЦК-структурой представлена исключительно сферолитами, что сопровождается преобладанием $<111>$ ориентации кристаллов, в отличие от электроосаждённого железа, в котором обычная мелкокристаллическая структура характеризуется преимущественной $<211>$-ориентацией кристаллов.

Key words: surface morphology, preferred orientations, $\mathrm{Fe}-\mathrm{Cr}-\mathrm{Ni}$ coatings, electrodeposited alloys, electrodeposited iron.

(Received November 28, 2014; in final version, February 2, 2015 )

\section{INTRODUCTION}

Electrodeposited iron coatings are used in the industry for restoration of dimensions and simultaneous surface hardening of the machine parts working in wear conditions [1-3].

Enhancement of the properties such as hardness and wear resistance of electrodeposited iron can be achieved by its alloying with other metals causing changes in structure formation of the deposits $[1,4,5]$.

Previously it was shown that introduction of ions of chromium [5-7] and nickel $[4,5,8,9]$ into the iron-plating electrolyte results in certain changes in surface morphology, phase composition, microstructure, and preferred crystal orientations in the produced coatings. Joint effect of nickel and chromium on structure formation of electrodeposited iron was also investigated [10-16]. The analysis of literature sources shows that the majority of research works of the electrodeposited iron-based alloys are directed mainly to electrochemical issues of their deposition, but their structure and phase composition usually got less attention. However, a few works discussing certain structural aspects of the ternary $\mathrm{Fe}-\mathrm{Cr}-\mathrm{Ni}$ alloys mainly deal with the coatings produced from chloride electrolytes [12-15].

Therefore, uncovering of joint influence of chromium and nickel on the processes of structure formation of electrodeposited iron-based coatings produced from sulphate electrolytes requires additional research.

It should be also noted that one of the possible reserves for enhancement of the complex of properties of iron coatings is the formation of certain preferred crystal orientations in their structure.

Preferred orientations in electrodeposited iron produced from both sulphate [17, 18] and chloride electrolytes [19] are thoroughly investigated. Quite wide experimental data is also available for $\mathrm{Fe}-\mathrm{Cr}[6,7]$ and $\mathrm{Fe}-\mathrm{Ni}[8,9]$ alloys. Nevertheless, preferred orientations in electrodeposited ternary $\mathrm{Fe}-\mathrm{Cr}-\mathrm{Ni}$ alloys remain less investigated. Previously, it was repeatedly shown that even low concentrations of additional metal ions in the electrolyte can cause drastic changes of crystal 
orientations in electrodeposited metallic materials, (see, e.g., works $[20,21])$. Therefore, the investigations of joint influence of nickel and chromium on preferred orientations in iron-based coatings seem to be of sufficient scientific interest.

It should be mentioned that structure and phase composition of electrodeposited metal coatings may differ from the equilibrium ones and essentially depend on the process parameters (current density and temperature) as well as on the electrolyte composition. Besides, the concentration ratios of the deposited metals in the electrolyte and in the coatings are different due to distinct deposition rates of the metals. So, the theoretical prediction of structure and properties of electrodeposited coatings remains difficult and thorough experimental investigations are still required in this field.

Therefore, the aim of this work is the determination of features of structure formation of electrodeposited iron-based coatings depending on chromium and nickel concentrations in the sulphate electrolyte.

\section{MATERIALS AND METHODS}

Iron, $\mathrm{Fe}-\mathrm{Cr}, \mathrm{Fe}-\mathrm{Ni}$ and $\mathrm{Fe}-\mathrm{Cr}-\mathrm{Ni}$ coatings of $15 \mu \mathrm{m}$ thickness are electrodeposited at the current density of $10 \mathrm{~A} / \mathrm{dm}^{2}$ and the temperature of $55-57^{\circ} \mathrm{C}$ from sulphate iron-plating electrolytes $(\mathrm{pH}=2-3)$ containing $80 \mathrm{~g} / \mathrm{l}$ ions of $\mathrm{Fe}, 0-20 \mathrm{~g} / \mathrm{l}$ ions of $\mathrm{Cr}, 0-20 \mathrm{~g} / \mathrm{l}$ ions of $\mathrm{Ni}$ (with the sources of the said metals being $\mathrm{FeSO}_{4} \cdot 7 \mathrm{H}_{2} \mathrm{O}, \mathrm{Cr}_{2}\left(\mathrm{SO}_{4}\right)_{3} \cdot 6 \mathrm{H}_{2} \mathrm{O}, \mathrm{NiSO}_{4}$. $\cdot 7 \mathrm{H}_{2} \mathrm{O}$, respectively) and $\mathrm{Al}_{2}\left(\mathrm{SO}_{4}\right)_{3} \cdot 18 \mathrm{H}_{2} \mathrm{O}-100 \mathrm{~g} / \mathrm{l}$ as a buffering substance. A soluble iron anode is utilized for deposition process. Industrial $0.5 \mathrm{~mm}$ thick low-carbon steel $08 \mathrm{kp}$ sheet is used as a substrate.

Surface morphology of the coatings was investigated by the method of scanning electron microscopy (SEM) at the REM-106I microscope. Phase composition was determined by the method of X-ray diffractometry (XRD) at the modernized diffractometer of DRON type in $\mathrm{Cu} K_{\alpha^{-}}$ radiation. The investigated coatings were not separated from the steel substrate due to their sufficient thickness. Preferred crystal orientations were estimated by the ratio of intensities of diffraction maxima on X-ray diffraction patterns.

\section{RESULTS AND DISCUSSION}

Phase composition of the investigated alloys coatings is presented solely by iron-based solid solutions with b.c.c. crystal structure. No intermetallic compounds were found by X-ray phase analysis of the coatings (see Fig. 1).

The contents of chromium and nickel in the $\mathrm{Fe}-\mathrm{Cr}$ and $\mathrm{Fe}-\mathrm{Ni}$ coatings indicate that at their low concentration in the electrolyte $(10 \mathrm{~g} / \mathrm{l})$ 
the deposition rate of chromium during co-deposition with iron is much higher than the one of nickel. The deposition rates become almost equal at $20 \mathrm{~g} / 1$ concentration. However, joint co-deposition of two alloying elements with iron results in prevalence of nickel over chromium in the coatings produced from the electrolytes with equal concentrations of chromium and nickel ions (see Table 1).

The X-ray diffraction results also show that alloying elements cause
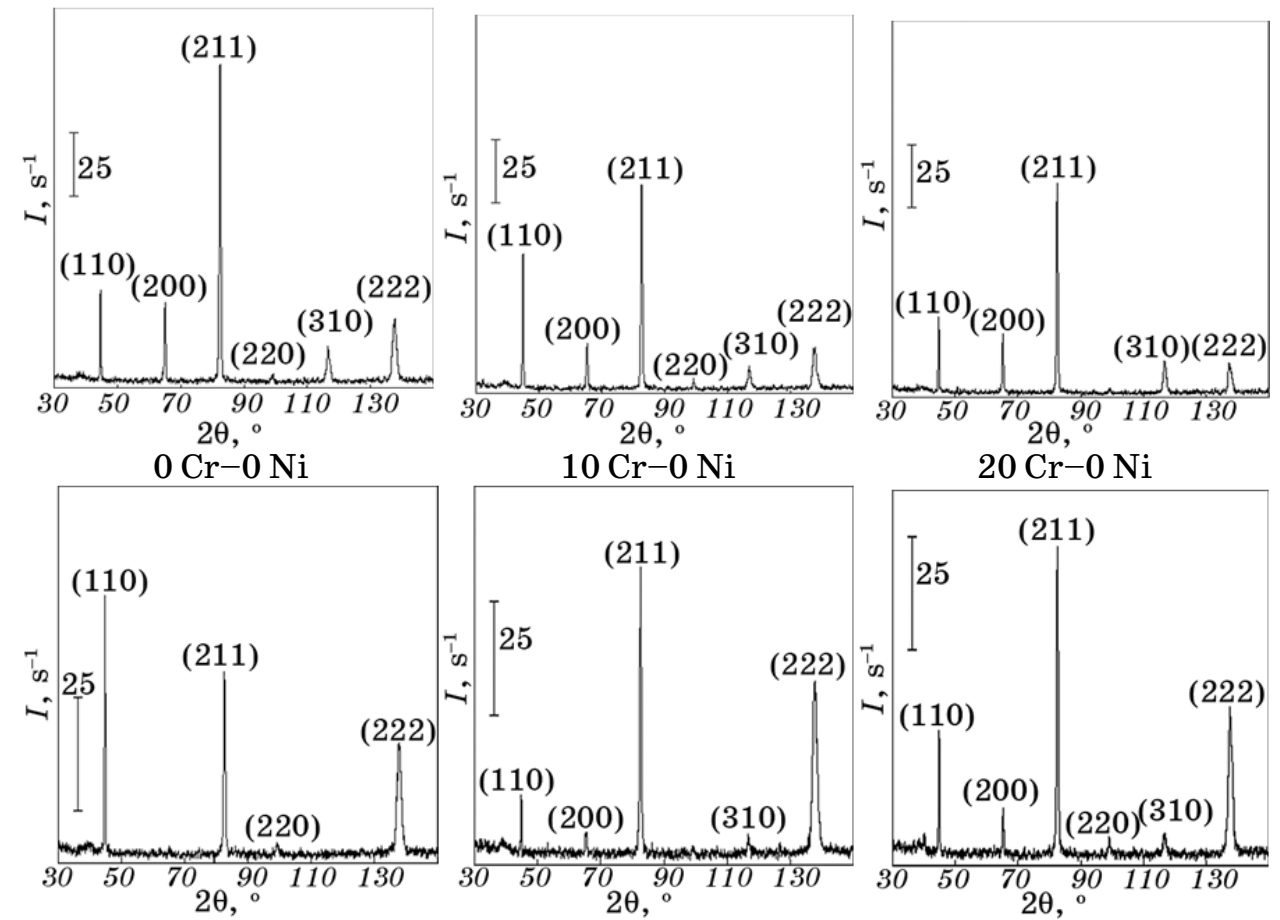

$10 \mathrm{Cr}-0 \mathrm{Ni}$

$$
20 \mathrm{Cr}-0 \mathrm{Ni}
$$
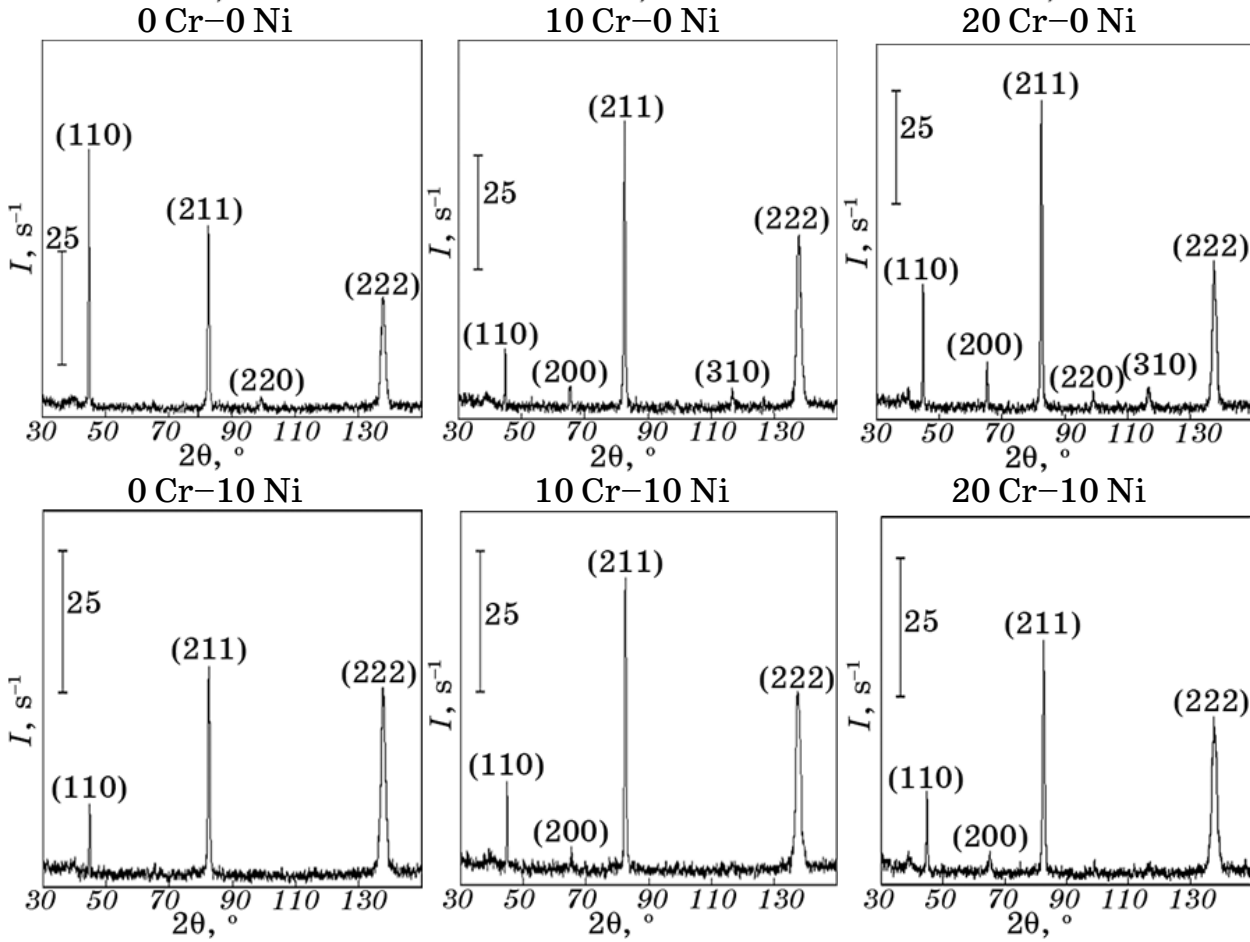

$10 \mathrm{Cr}-10 \mathrm{Ni}$

$20 \mathrm{Cr}-10 \mathrm{Ni}$

$0 \mathrm{Cr}-20 \mathrm{Ni}$
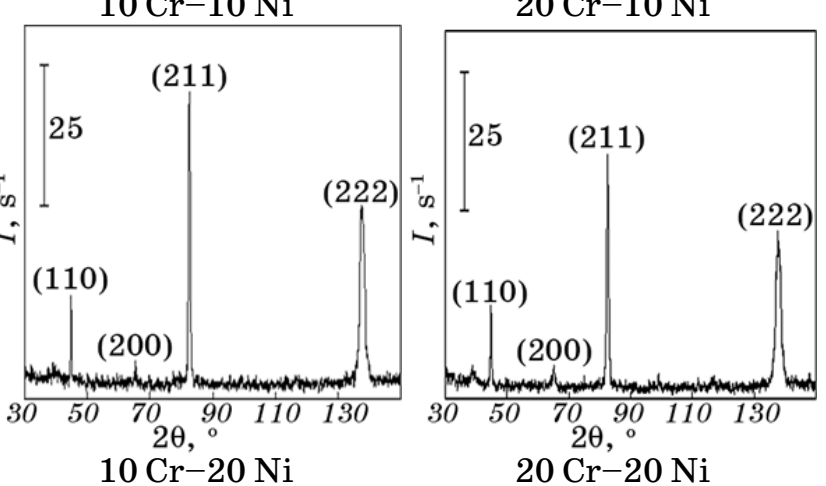

Fig. 1. X-ray diffraction patterns of electrodeposited iron-based coatings fabricated at various $\mathrm{Cr}$ and $\mathrm{Ni}$ concentrations $(\mathrm{g} / \mathrm{l})$ in the sulphate electrolyte. 
TABLE 1. $\mathrm{Cr}$ and $\mathrm{Ni}$ concentrations in the iron-based coatings depending on their concentrations in the sulphate electrolyte.

\begin{tabular}{c|c|c|c}
\hline \multirow{2}{*}{$\begin{array}{c}\text { Ni concentration in } \\
\text { the electrolyte, g/l }\end{array}$} & \multicolumn{3}{|c}{ Cr concentration in the electrolyte, g/l } \\
\cline { 2 - 4 } & 0 & 10 & 20 \\
\hline 0 & - & $1.15 \% \mathrm{Cr}$ & $1.33 \% \mathrm{Cr}$ \\
10 & $0.42 \% \mathrm{Ni}$ & $0.48 \% \mathrm{Cr}+0.64 \% \mathrm{Ni}$ & $1.18 \% \mathrm{Cr}+0.53 \% \mathrm{Ni}$ \\
20 & $1.27 \% \mathrm{Ni}$ & $0.86 \% \mathrm{Cr}+1.34 \% \mathrm{Ni}$ & $1.27 \% \mathrm{Cr}+1.74 \% \mathrm{Ni}$ \\
\hline
\end{tabular}

certain changes in crystal orientations in the coatings, which can be estimated by relative intensities of the diffraction maxima (see Fig. 1). Thus, while iron coatings without alloying possess strong $<211>$ crystal orientation, introduction of nickel into the electrolyte results in drastic growth of $<\mathbf{1 1 1}>$ orientation. Introduction of chromium into the electrolyte seems to have no significant influence on preferred orientations in the coatings. Somewhat decrease of overall diffractionpattern intensity of $\mathrm{Fe}-\mathrm{Cr}$ alloys relative to the one of the electrodeposited iron may be caused by presence of chromium atoms in the alloys. In addition, some increase of the intensity of (110) diffraction maximum in the $\mathrm{Fe}-\mathrm{Cr}$ alloy produced at $10 \mathrm{~g} / \mathrm{l}$ chromium concentration should be noted but the integral intensity of the maximum is too low to indicate the presence of the corresponding crystal orientation.

Further calculation of the integral intensities of the found diffraction maxima and their comparison with the ones of the reference diffraction pattern of pure iron indicate that $<111>$ crystal orientation dominates over $<211>$ in the both investigated $\mathrm{Fe}-\mathrm{Ni}$ and $\mathrm{Fe}-\mathrm{Cr}-\mathrm{Ni}$ alloys. The quantitative change in the found preferred orientations of crystals can be estimated by the ratio of the respective pole densities calculated from the obtained X-ray diffraction patterns (see Table 2). Thus, the presence of nickel in the electrolyte and in the coatings should be considered as the cause of change of the preferred crystal orientation in the coatings from typical for electrodeposited iron $<211>$ to the found $<111>$.

TABLE 2. Ratio of pole densities $P_{222} / P_{211}$ in the iron-based coatings depending on chromium and nickel concentrations in the sulphate electrolyte.

\begin{tabular}{c|c|c|c}
\hline \multirow{2}{*}{$\begin{array}{c}\text { Ni concentration in } \\
\text { the electrolyte, } \mathrm{g} / \mathrm{l}\end{array}$} & \multicolumn{3}{|c}{ Cr concentration in the electrolyte, $\mathrm{g} / \mathrm{l}$} \\
\cline { 2 - 4 } & 0 & 10 & 20 \\
\hline 0 & 1.79 & 1.77 & 1.28 \\
10 & 5.45 & 5.45 & 3.46 \\
20 & 8.57 & 5.08 & 5.38 \\
\hline
\end{tabular}


The alloying elements also cause decent changes in surface morphology influencing crystal shape and size as well as surface relief of the investigated electrodeposited coatings (see Fig. 2).

Thus, without alloying, surface structure of the iron coatings is mainly represented by fine crystals sized less than $1 \mu \mathrm{m}$ and by a few more coarse crystals. However, introduction of nickel into the electrolyte changes the structure type of the coatings initiating the formation of spherulites, i.e., crystal aggregates of radial-beam configuration consisting of the core and the peripheral part [22, 23]. Such type of structure of electrodeposited coatings is classified as quasi-crystal [24].

The formation of spherulites as one of the possible forms of growth of electrodeposits [23] is usually explained by the increase of local current density in the crystallization centres at the initial stage of electrodeposition (which causes nucleation rate of spherulites to exceed their growth rate and results in appearance of spherulite cores consist-
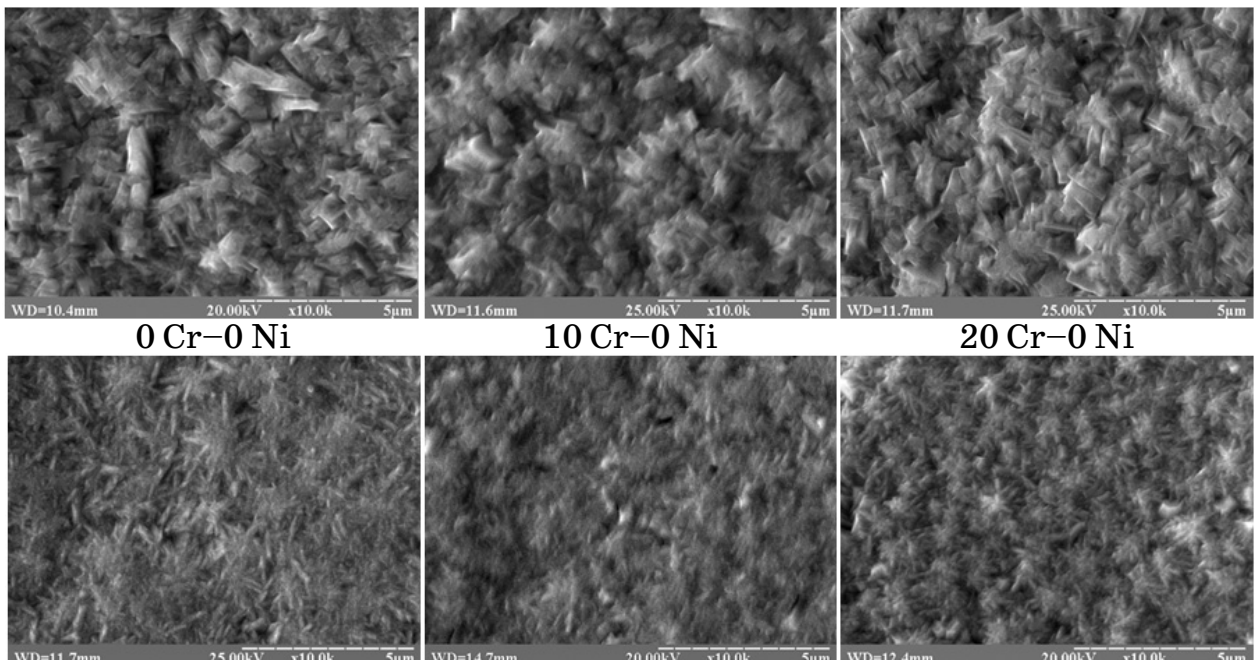

$20 \mathrm{Cr}-0 \mathrm{Ni}$

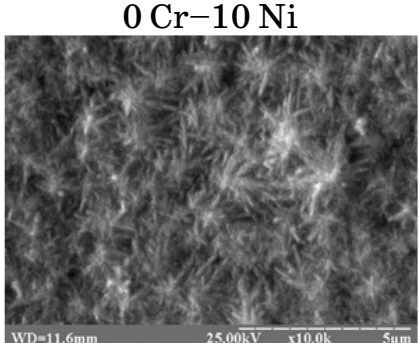

$0 \mathrm{Cr}-20 \mathrm{Ni}$
$10 \mathrm{Cr}-10 \mathrm{Ni}$

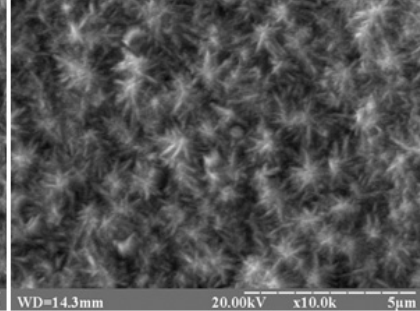

$10 \mathrm{Cr}-20 \mathrm{Ni}$

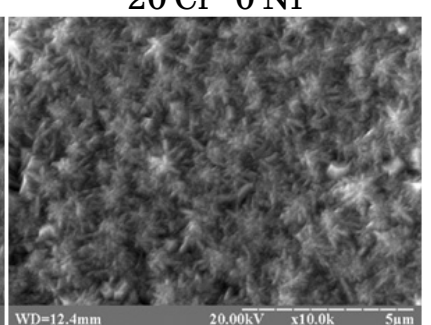

$20 \mathrm{Cr}-10 \mathrm{Ni}$

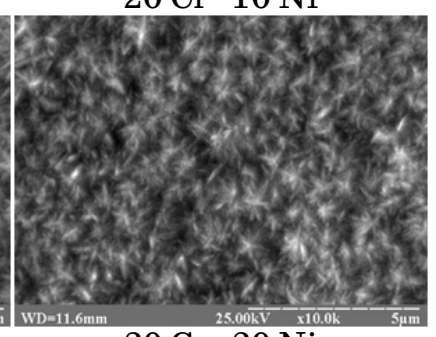

$20 \mathrm{Cr}-20 \mathrm{Ni}$

Fig. 2. Surface morphology of electrodeposited iron-based coatings depending on $\mathrm{Cr}$ and $\mathrm{Ni}$ concentrations $(\mathrm{g} / \mathrm{l})$ in the sulphate electrolyte. 
ing of fine randomly oriented crystals) and its subsequent decrease during further growth of cores with the formation of radial-beam periphery of the aggregates [22].

In contrast to nickel, introduction of chromium into the electrolyte does not lead to fundamental changes of structure type of the coatings and is accompanied by the formation of more uniform structure with regard to the crystal size (see Fig. 2). Crystal cut becomes more distinct in this case.

The surface structure of the investigated ternary $\mathrm{Fe}-\mathrm{Cr}-\mathrm{Ni}$ alloys is also represented by spherulites. However, at the presence of chromium, the spherulite structure of the alloys caused by the presence of nickel undergoes some minor changes. Spherulites become more distinct, their peripheral part is less developed, and the surface is less smooth. These features indicate that, at the presence of chromium, the growth of spherulites and their intergrowth are hindered.

Therefore, the discovered apparent interdependence between the appearance of $<\mathbf{1 1 1}>$ crystal orientation and the formation of spherulites in the nickel-containing alloys-both $\mathrm{Fe}-\mathrm{Ni}$ and $\mathrm{Fe}-\mathrm{Cr}-\mathrm{Ni}-$ should be considered as the main result of the performed combined XRD and SEM investigations of the iron-based coatings.

\section{CONCLUSIONS}

The combined SEM and XRD structural investigations of electrodeposited $\mathrm{Fe}-\mathrm{Cr}-\mathrm{Ni}$ alloys produced from sulphate electrolytes show significant changes in surface morphology and crystal orientations of the coatings in comparison with electrodeposited iron without alloying.

The surface morphology of the investigated $\mathrm{Fe}-\mathrm{Cr}-\mathrm{Ni}$ alloys with b.c.c. crystal structure is represented solely by spherulites that is accompanied by prevalence of $<\mathbf{1 1 1}>$ crystal orientation in contrast to electrodeposited iron without alloying where regular fine crystal structure is characterized by preferred $<211>$ crystal orientation.

Further investigations could be directed to the investigations of the mechanical properties of electrodeposited iron-based coatings containing chromium and nickel with regard to the found structural features.

\section{REFERENCES}

1. E. D. Pleshka, Surf. Eng. Appl. Elect., 44, No. 4: 264 (2008).

2. V. A. Likhachev, Galvanotekhnika i Obrabotka Poverkhnosti, 14, No. 1: 14 (2006) (in Russian).

3. D. M. Kroitoru, G. V. Gur'yanov, Zh. I. Bobanova, and N. I. Botoshan, Surf. Eng. Appl. Elect., 44, No. 6: 436 (2008).

4. Ie. Kolesnyk, Chimia, 67, No. 7/8: 575 (2013).

5. Ie. V. Kolesnyk, Proc. of Conf. 'Modern Problems of Surface Chemistry' (May 
20-21, 2014) (Kyiv: O. O. Chuiko Inst. of Surface Chemistry: 2014), p. 123.

6. Ie. V. Kolesnyk and M. T. Velychko, Metaloznavsto ta Termichna Obrobka Metaliv, 63, No. 4: 64 (2013) (in Russian).

7. F. Wang and T. Watanabe, Mater. Sci. Eng. A, 349, Nos. 1-2: 183 (2003).

8. Ie. V. Kolesnyk, Scientific Bulletin of National Mining University, 137, No. 5: 62 (2013) (in Russian).

9. K. Nakamura, M. Umetani, and T. Hayashi, Surf. Technol., 25, No. 2: 111 (1985).

10. C. U. Chisholm and R. J. G. Carnegie, Electrodeposition and Surface Treatment, 1, No. 5: 367 (1973).

11. T. M. Harris, G. M. Whitney, and I. M. Croll, J. Electrochem. Soc., 142, No. 4: 1031 (1995).

12. H. Adelkhani and M. R. Arshadi, J. Alloy Compd., 476, Nos. 1-2: 234 (2009).

13. L. Sziráki, E. Kuzmann, M. El-Sharif, C. U. Chisholm, G. Principi, C. Tosello, and A. Vértes, Electrochem. Commun., 2, No. 9: 619 (2000).

14. L. Sziráki, E. Kuzmann, C. U. Chisholm, M. El-Sharif, L. Bybics, and S. Stichleutner, Central European Journal of Chemistry, 5, No. 4: 931 (2007).

15. A. Vértes, A. Watson, C. U. Chisholm, I. Czaky-Nagy, E. Kuzmann, and M. El-Sharif, Electrochim. Acta, 32, No. 12: 1761 (1987).

16. Ie. V. Kolesnyk, Metaloznavstvo ta Termichna Obrobka Metaliv, 56, No. 1: 58 (2012) (in Russian).

17. Ye. V. Kolesnyk, Metallofiz. Noveishie Tekhnol., 33, Special Issue: 401 (2011) (in Russian).

18. Ie. V. Kolesnyk and M. T. Velychko, Metaloznavstvo ta Termichna Obrobka Metaliv, 54, No. 3: 26 (2011) (in Russian).

19. S. Yoshimura, S. Yoshihara, T. Shirakashi, and E. Sato, Electrochim. Acta, 39, No. 4: 589 (1994).

20. F. Czerwinski, J. A. Szpunar, and K. Kondo, J. Mater. Sci., 33, No. 10: 2589 (1998).

21. F. Czerwinski and J. A. Szpunar, Texture Microstruct., 32, Nos. 1-4: 107 (1999).

22. I. M. Kovenskiy and V. V. Povetkin, Metallovedeniye Pokrytiy (Metals Science of Coatings ) (Moscow: Intermet. Engineering: 1999) (in Russian).

23. A. A. Vikarchuk, Elektrokhimiya, 28, No. 7: 974 (1992) (in Russian).

24. E. A. Mamontov, L. A. Kurbatova, and A. P. Volenko, Elektrokhimiya, 21, No. 9: 1211 (1985) (in Russian). 